\title{
Comparison Between Conservation System of a Coastal Type of National Park of Korea and Japan - Focused on Taean-Haean National Park -
}

\author{
Tae-Dong Jo and Okano Takahiro* \\ College of Life Science, Kangnung National Univ., Kangnung 210-702, Korea \\ *Natural Environment Bureau, Ministry of the Environment, Tokyo 100-8975, Japan
}

(Manuscript received 14 December, 2002 ; Accept 24 January, 2003)

\begin{abstract}
The resources conservation system is comprehended, making Taean-haean National Park a research material by applying the fact of landowning, designating an LOP and Korea and Japan's Natural Park Act. Following conclusions were obtained in this study; Most of land areas of the National Park are privately owned; Only a few have been designated as Natural Reservation, a core reserved area on LOP, and a sandy beach, a sand dune, a sand spit, a tidal flat, a wetland, etc are distributed in the natural environment area so they were exposed to development; As seen in most of coastal type of National Parks, 13 commercial beaches are established. The annual rush to the beaches appears in July and August; Sand dune areas that have to be managed in terms of conservation, are turned into beaches. Moreover, the collective facilities areas are randomly developed. So they fail to function originally; The current Natural Park Act has no systematic devices for conservation of the natural resources on the seashore or offshore.
\end{abstract}

Key words : Taean-haean National Park, Conservation system, Land on purpose, Natural reservation

\section{Introduction}

There are a lot of natural resources on the seashore or offshore, but some of these areas of Korea have been reclaimed and disorderly developed to sight-seeing spots like sea bathing beaches. However the result of a recently reclaimed land in Sihwa lake or a Saemankeum reclamation site gives us a good lesson in such an environmental aspect as destruction of ecosystem. Among of about 30 related regulations in charge, such as the Seashore Management Act, the Public Surface of the Water Management Act, the Realm Use Management Act, a National Park established by the Natural Park Act can be such a good system in terms of conservation.

Corresponding Author ; Tae-Dong Jo, College of Life Science, Kangnung National Univ., Kangnung 210702, Korea

Phone : +82-33-640-2350

E-mail : chol16@knusun.kangnung.ac.kr
Twenty of Korean National Parks are currently designated and the land area is approximately $3,825 \mathrm{~km}^{2}$, about $2,649 \mathrm{~km}^{2}$ is that sea areas of coastal National Parks which amazingly accounts for about $69 \%$ of park area, and only $6.5 \%$ of total national territory ${ }^{1)}$. Despite the unique qualities and resources of coastal areas, the current Natural Park Act fails to make institutional devices to problems caused by designating an LOP (land on purpose) just the way a land park is done or by how it is used.

In this study, the problem of resources conservation system is comprehended, making Taean-haean National Park a research material by applying the fact of landowning, designating an LOP and Korea and Japan's Natural Park Act. The purpose of this study is to show the way of how to make National Park policy sustainable through the environmental conservation and proper use of coastal type Korean National Parks. 


\section{Methods}

Taean coast, which is designated as the 13th National Park in 1978 largely consists of hilly areas around Taean peninsular and Anmyun island. It is a typical rias coast $530 \mathrm{~km}$ long. The difference between the rise and fall of the tide is huge and its coastline is frequently changed, so it is variously shaped, for example, a tidal flat, a beach, a sand spit, a sand dune, etc.

Not only by having an on the spot interview with officials concerned of Taean-haean National Park, but also through the aspects of landowning and the designation of LOP, a variety of problems of that area have been grasped. The current issues were investigated in conservation aspects around the Natural Park Act concerned with National Parks of a Seashore Type, compared with that of Japanese. Problems described above were discussed comprehensively. On the ground of that, it was proposed that conservation system of the National Parks of Coastal-type should be established.

\section{Results and Discussion}

\subsection{The present state of landowning}

As seen in Table 1, a demesne accounts for about $71 \%$ of this area even though it is within a National Park. It seemed like to lose its value as a National Park defined by IUCN, the US which gave birth to the National Park system in $1872^{2)}$. Since most of lands are privately owned, development is a natural thing for making a profit originated from landowners' privilege and desire. Therefore park conservation could be relatively difficult. Except sand dune areas, that is a kind of reservation, a revetment, a cliff, a building, and a building object are presently constructed in a demesne. So it

Table 1. The present state of landowning (Limited on land area) (Land area is $38.69 \mathrm{~km}^{2}$; \%)

\begin{tabular}{ccc}
\hline Demesne & State demesne & Public domain \\
\hline 70.6 & 1.1 & 28.3 \\
\hline Note : $\begin{array}{l}\text { Taean-haean National } \\
(2000)\end{array}$ & Parks & Authority's data \\
\end{tabular}

is needed that the fundamental measures should be taken against this.

\subsection{Conditions of the designation of LOP}

Table 2 indicates that a Natural Reservation, a center of resource conservation consists of a part of only $0.01 \%$. That actually means the conservation system is almost meaningless.

Sand dune (Table 3), sandy beach, sand spit, natural monument, wetland, tidal flat, etc., which are very environmentally important, have coexisted in this National Park ${ }^{3)}$. However, the fact that most of them are privatized and the natural environment area largely lies in sea areas, shows that it is not suitable for the aim of the Natural Park Act. In Taean-haean National Park, 13 major beaches have been designated from north to south, as Table 4 seen, 23 sand dunes are also formed. Eleven dunes larger than $0.1 \mathrm{~km}^{2}$ are distributed on of $5 \mathrm{~km}^{2}$ of total area. The problem is that the situation is badly affected by development of beaches from sand dunes, construction of buildings, cliffs, revetments on them, or designation of a collective facilities area.

\subsection{Application of Korea and Japan's Natural Park Act to National Parks of a seashore type}

\subsubsection{The Natural Park Act of Korea}

The Natural Park Act has in Korea not been specially applied to National Parks of a Coastal-type. Of all provisions of the Natural Park Act, the related clauses have been extracted. This study goes on from them ${ }^{4)}$.

Article 18 has specified that action in LOP within the National Parks of Coastal-type can be altered by the Minister of Environment Act, but Article

Table 2. The present conditions of LOP

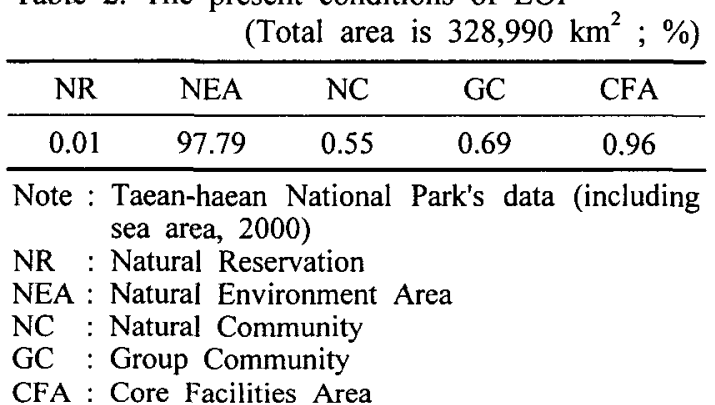


Comparison Between Conservation System of a Coastal Type of National Park of Korea and Japan 153 - Focused on Taean-Haean National Park -

11 of the Enforcement Regulations only has the division of the island area and the coastal area. There are no special laws concerning seashore or offshore matters so LOP should be subdivided in consideration of resource, use condition, and relationship with a demesne. Of act permission clauses of Article 23, it's stated that slight matters prescribed by a Presidential decree, a clue provision can be reported to the Parks Management Authority or not. In Taean-haean case, it's so crowded in July and August in which any kind of street stalls or temporary buildings are rampant and a variety of environmental destruction is done by users. The problem is that the existing Natural Park Act says reports can be omitted without any detailed standards.

\subsubsection{Japanese Natural Park Act}

Japan is surround by sea. Standards for a seashore and offshore issue are apparently prepared. The underwater park zone is a typical example. According to Article 24 of Japanese Natural Park Act, the underwater park zone is designated to strictly conserve sea livings such as tropic fish, corals, or seaweeds and specially scenic areas among submarine scenery which belongs to the submarine geography, which is all about maintaining the underwater scenery of the national or national authorized parks ${ }^{5)}$. The system of the submarine park zone, which means a special reservation in the sea area has been established by amendment of the Natural Park Act in 1970. This is aimed at conservation and utilization of the submarine scenery, while the old one had the key subject of landscape conservation and reasonable utilization

Table 3. Importance of a sand dune and problems by development

\begin{tabular}{|c|c|}
\hline Importance of a sand dune & Problems following development \\
\hline $\begin{array}{l}\text { 1. Functioning as a buffer zone between the } \\
\text { marine ecosystem and the land ecosystem. } \\
\text { 2. As sand depots, when sand in sea park is } \\
\text { washed away artificial supplement is impossible. } \\
\text { 3. Serving for a natural breakwater by being } \\
\text { located between land and sea. } \\
\text { 4. Underground water storage, conservation, and } \\
\text { purification. } \\
\text { 5. Providing a rare plant or animal with a habitat. } \\
\text { 6. Forming a natural beauty. }\end{array}$ & $\begin{array}{l}\text { 1. A sand dune adjacent to seashore is largely used as } \\
\text { a sea resort, especially in Manripo, Hwaampo, and } \\
\text { Mongsanpo Collective Facilities Area itself is formed } \\
\text { on a sand dune, so the original form is greatly } \\
\text { destroyed. } \\
\text { 2. Since a shore pine community prepared for a } \\
\text { windbreak behind the sand dune area is used as a } \\
\text { camping ground in the summer, all neighboring sand } \\
\text { dunes are more and more damaged by continual } \\
\text { pressure. } \\
\text { 3. In case of artificial building objects built on a sand } \\
\text { dune, a sand dune is damaged according to a density } \\
\text { of visitors, since public facilities like residential } \\
\text { space, a temporary structure for the summer season, } \\
\text { a toilet, and so on, are installed. } \\
\text { 4. In } 8 \text { beaches, like Manripo, the construction of a } \\
\text { revetment, a stone wall for reinforcement a total of } \\
\text { 6.8km long prevents a sand beach and a sand dune } \\
\text { from exchanging sand, and a sand-lessening pheno- } \\
\text { menon presents itself badly in the sand dune area } \\
\text { because a revetment is constructed in that area. } \\
\text { 5. Since the sand dune area mainly consists of private } \\
\text { lands, civil petitions are presented from restricting } \\
\text { the utilization of private property. Therefore it is } \\
\text { difficult to push ahead with the Dunes Conservation } \\
\text { Project. }\end{array}$ \\
\hline
\end{tabular}

Note : based on Ministry of Environment data (2000)

Table 4. Major beaches and sand dune distribution

\begin{tabular}{cc}
\hline Beaches & Sand dunes \\
\hline 13 of sites & 23 of sites (13 being developed into beaches) \\
\hline Note $:$ Taean-haean National Park data $(2000)$ &
\end{tabular}

Note : Taean-haean National Park data (2000) 
under that condition. Japan, as you see, set the standards for the seashore and offshore conservation and utilization about 30 years ago, and the management plan is thoroughly made under those standards.

\section{Conclusions}

Korean Ministry of Environment amended the Natural Park Act for the National Parks in 2001 , but without conservation of the diversity of life on earth propelled by advanced countries or improvements in the Natural Reservation which has the problem of environmental protection, it was revealed that it was the bill that just contains a legal permission of picking eatable wild plants or Sannamul (food plants) or installing cable ways and tracks in those areas. This was the same administrative action as the Ministry of Construction's developmentoriented policy of the past. So it is doubtful that basic ideas on conservation and utilization of the National Parks are established. On the contrary, Japanese Ministry of Environment amended their Natural Park Act in view of conservation of biodiversity in 2002. From it, the protection policy of National Parks has been fortified, and the Use Regulation Zone system, the Scenery Conservation Agreement system, and Close-Regional Management have been carried out ${ }^{6-7)}$. This amendment can strongly suggest that National Parks are not administrated by national or local governments alone, but it is needed of all-out efforts that local residents, environmental groups, and the nation alike should make concerning the nationalpark policy of Korea.

Following conclusions were obtained in this study.

1) Most of land areas of the National Park are privately owned.

2) Only a few have been designated as $\mathrm{Na}$ tural Reservation, a core reserved area on LOP, and a sandy beach, a sand dune, a sand spit, a tidal flat, a wetland, etc are distributed in the natural environment area so they were exposed to development.

3) As seen in most of Coastal-type National Parks, 13 commercial beaches are established. The annual rush to the beaches appears in July and August.
4) Sand dune areas that have to be managed in terms of conservation, are turned into beaches. Moreover, the collective facilities area is randomly developed. So they fail to function originally.

5) The current Natural Park Act has no systematic devices for conservation of the natural resources on the seashore or offshore.

On the basis of conclusion presented above, We propose following National Park policies on the ground of the environmental conservation of National Parks of Coastal-type.

1) Taean-haean National Park and its surroundings need to be thoroughly investigated academically, ecologically, scenically, and aesthetically. Then institutional devices should be made for conservation's sake, at the same time designation of LOP should be reregulated from that point of view. Also landowning situation is surveyed and compared.

2) Therefore places that do not have value as park should be expunged from the park district, On the other hand, if they have the value although they're not designated, they should be included and organized into LOP, which is divided into reservation and use zone separately. Even a demesne, if it has high value should be purchased by government or a conservation agreement with residents as conducted in Japan needs to be concluded.

3) Environmental problems that occurred to local residents and other users who rush to that area in July and August, should be investigated and analyzed, then conservation and utilization plans have to be prepared.

\section{References}

1) National Parks Authority, 2001, A National Parks White Paper, 1-58.

2) Jo, T. D., 1999, Apprehension of an Environmental Landscape, Seoul, Munundang, 1$329 \mathrm{pp}$.

3) Minister of Environment (Korea), 2002, A Guide Book for Preservation \& Management of the coast sand dune, 1-50pp. 
Comparison Between Conservation System of a Coastal Type of National Park of Korea and Japan 155

- Focused on Taean-Haean National Park -

4) Jo, T.D., 1997, A Study for the Improvement of the Zoning of Nature Parks of Korea, Focused on Nature Preservation Zone and Natural Environment Zone of National Parks. The Journal of Korea Planners Association 32(5), 185-202.

5) Ishii, H., 1985, Green tract Planning, Chikyusya 1-199.
6) Minister of the Environment (Japan), 2003, References to the partial revision of the Natural Park Act, 10-19pp.

7) Jo, T. D. and T. Okano, 2002, A study on the national park policy focused on the revision of Japanese Natural Park Act, Proceedings of the Korean Environmental Sciences Society Conference, May. 366. 